\title{
Marijuana Use and Behavioural Outcomes among Adolescent Youths in Akwa lbom State, Nigeria
}

\author{
Essien, Blessing Stephen (PhD) \\ Department of Sociology/Anthropology, Faculty of Social Sciences, University of Uyo \\ Email: essienblessing99@yahoo.com \\ Inyang, Ekaette Mary \\ Department of Sociology/Anthropology, University of Uyo \\ James, Sylvester Anthony \\ Department of Sociology/Anthropology, University of Uyo \\ Emeh, Phyllis Bassey \\ Department of Political Science, Akwa Ibom State University \\ Email: emehphyllis@yahoo.com
}

\section{Doi:10.5901/mjss.2016.v7n5p349}

\section{Abstract}

The study investigated the effects of marijuana use on the behaviour of adolescent youths in Ibesikpo Asutan Local Government Area of Akwa Ibom State, Nigeria. The population consisted of all adolescent youths of the study area. The study purposively adopted 200 respondents as its sample size in view of the non-availability of data on the actual number of adolescents that use marijuana in the study area. Snow ball sampling technique was used in selecting the respondents. A 35items structured questionnaire was used to measure the substantive issues. Only one hundred and ninety-seven copies of questionnaire administered to 200 marijuana users were found useful. Simple percentages and chi-square statistics $\left(x^{2}\right)$ was used in data analysis. Data analysis revealed marijuana use and associated behavioural effects among adolescent youths in Ibesikpo Asutan Local Government. Finding shows a significant association between marijuana use and disrespectful behaviour among adolescents. Equally, a significant relationship between marijuana use and criminal behaviour among adolescent youths was found. Further findings revealed a significant association between marijuana use and financial mismanagement among youths of the study area. The study recommended that parents should be up and doing in the task of care giving to their wards; particularly, being watchful on the company kept by their wards. Campaigns against marijuana use should be incorporated in health education curriculum for primary, secondary, and tertiary institutions with special focus on the nature and consequences of drugs. In the same vein, the fight against drug abuse including marijuana by law enforcement agencies (Nigeria Police Force, National Drug Law Enforcement Agency, and the National Agency for Food, Drug Administration and Control) should be intensified. The collaboration of Law Enforcements with traditional institutional structures not just in checking the drug suppliers but also the users could be helpful in this regard.

Keywords: Marijuana, Behavioural outcomes, Adolescents, Nigeria.

\section{Introduction}

The United Nations Organization on Drugs and Crime (UNODC, 2005) stated that "marijuana use is a major public health problem all over the world". The use of it by adolescents in Nigeria has become one of the most disturbing health related problems. Due to its use, several adolescents' youths has experienced psychological health problems, as some of them have become insane, maladjusted to school situations and eventually drop out of school.

In Akwa Ibom State, alarming evidence in the prevalence of marijuana use and its effects on youth behaviour has been noted. Data from the National Drugs Law Enforcement Agency Akwa Ibom State Command revealed that there were 353 male users while that of the female counterparts was 48. This number excluded a significant others who use the substance extensively but are neither being caught nor booked. Data revealed that from January 2015 till date, a total 
of 201 males and 36 females' suspects arrested from different Area Commands have been recorded so far in the first quarter of investigation (NDLEA, 2015).

The effects of substance abuse are varied including physical, social as well as psychological problems. Some of the risk factors includes feeling sad or having mental problems, psychic addiction (the urge to relax, enjoy and be happy and to feel comfortable), circulatory disturbances (dizziness or even fainting), unexpected accident, higher concentration in internal processes (one's own emotions, thought and perceptions), respiratory problems and impairment of one's memory (NDLEA, 2015). Osarenren (2002) also observed that addiction to marijuana use could cause truancy and absenteeism in school and at work. According to him "armed robbery; prostitution and high risk sexual behaviour as well as hostility to family, friends and teachers are also effects of marijuana use". Other effects according to Fabuyi (2000: 5) include "disruption of interpersonal relationships particularly within the family, marginalization, criminal behaviour, school failure, vocational problems and failure to achieve normal adolescent growth". Anthony (2012: 40) added that "marijuana addiction can lead to personality disorder among youths such as stubbornness, rigidity, poor social skills, selfcentredness, depression, and feeling of hopelessness and lack of respect for elders".

In a related study conducted among colleges of education students in Benin, Edo State, Fayombo (2000), Obianwu (2005), Omage and Oshiloya, (2006), discovered that "students and youths of easy virtue in that community were involved in marijuana use and stimulants such as amphetamines and cannabis". The Nigerian National Drug Law Enforcement Agency (NDLEA, 2015) corroborated the fact by noting that marijuana use is a major problem particularly in schools, colleges and universities and the Nigerian society at-large. Many of the youth's behaviours are linked to friendship and peers culture. Adolescence always want to be like others and to feel very important; and this reason account for marijuana use and other forms of substances.

Adolescents who use marijuana are found to typically exercise low self-esteem and lack of respect for people (Obianwu, 2005). Obianwu (2005) observed that "parents and peers influence adolescent marijuana use by acting as role models". Obianwu, (2005) further opined that "parental deprivation due to death, divorce, separation or discord has also been strongly associated with marijuana use". Now a day, lots of adolescent youths strongly rely on drugs for their day to day activities. Such drugs include tobacco, marijuana (Indian hemp), cocaine, morphine, heroine, alcohol, ephedrine, caffeine, glue, and barbiturates.

In Akwa Ibom State youths between ages 12-25 use marijuana (NDLEA 2015). This evidently could be adduced that more Nigerian youths are becoming drug dependants. Young ones who are sometimes from wealthy families are often seen with the use of substance like marijuana and cocaine. Staff (2012:3), stated that "marijuana (Indian hemp), which is frequently used in Nigeria and other substances like methamphetamine and tablet such as codeine capable of intoxicating are sometimes found in schools children". It is also estimated that over 1.5 million adolescent youth's smokes marijuana in Nigerian higher institutions and an estimated number of 2.5 million adolescent youths in various communities use marijuana (Alabi, 2012). In Akwa Ibom State, arrests made by the Police and the NDLEA, revealed that Ibesikpo Asutan Local Government Area has a high prevalence of marijuana usage (NDLEA Akwa Ibom State Command, 2015).

Nevertheless, the use of marijuana in all ramifications is a social problem. This problem affects all and sundry. The NDLEA revealed that drugs like marijuana and tobacco wreak individuals, shatter families and weaken entire society with burden of economic looses, health cost, increased lawlessness and crime. Akanbi and Ajiboye,( 2014) corroborated this fact by noting that in many societies the use of hard drugs is associated with family breakdowns; violence and destruction; child abuse; sexual abuse; wife abuse; disrespect and breakdown of law and order in families and society; as well as lost of individual dignity; respect and self worth; financial mismanagement and loss of property.

Research exits on the effect in which abuse of drugs have on the wider society generally (Ajayi and Ekundayo, 2010; Akanbi and Ajiboye, 2014), a few others centres on the impact of drug abuse on the academic achievements of students in educational institutions with emphasis on tobacco, cocaine, and alcohol (Nwankwo, Obi and Nwosu, 2013; Abdu-Raheem 2013; Agbonghale and Okaka 2014). However, literature is limited in respect of marijuana use and behavioural outcomes of adolescent youths in Nigeria. Moreover, no such study has been carried out in lbesikpo Asutan Local government Area of Akwa Ibom State despite the preponderance of the substance. Therefore, the study seeks to address these gaps. The study's contribution in awareness, behaviour modification and adjustment, and policy formulation dimensions need not be overemphasized.

The major objective of the study therefore is to examine the associated behavioural outcomes of marijuana use among youths of Ibesikpo Asutan Local Government Area. Specifically, the study seeks:

i) To examine whether marijuana use has effects on the behaviour of adolescent youths in Ibesikpo Asutan Local Government Area.

ii) To identify whether disrespectful behaviour is associated with marijuana use among adolescent youths of the 
study area.

iii) To assess whether marijuana use among youths in Ibesikpo- Asutan is associated with criminal behaviour.

iv) To investigate whether financial mismanagement is a behavioural effect of marijuana use among youths in Ibesikpo - Asutan.

\section{Research Hypotheses}

The following research hypotheses were formulated for the study:

Ho1: Marijuana use has no significant effects on the behaviour of adolescent youths in Ibesikpo Asutan Local Government.

Ho2: There is no significant association between marijuana use and disrespectful behaviour among adolescent youths in Ibesikpo Asutan Local Government.

Ho3: There is no significant association between marijuana use and criminal behaviour among adolescent youths in Ibesikpo Asutan Local Government.

Ho4: Financial mismanagement is not a statistically significant effect of marijuana use among adolescent youths in Ibesikpo Asutan Local Government.

\section{Literature Review and Theoretical Framework}

\subsection{Meaning and Nature of Marijuana}

According to the National Institute of Drug Abuse (NIDA, 2015) Marijuana is "a greenish-gray mixture of the dried, shredded leaves, stems, seeds and flowers of cannabis sativa, the hemp plant". It often goes with different names in different climes. They are often referred to as "pot", "grass", "reefer", "weed", "herb", "stone", "ganja", "Mary Jane - M J" (NIDA, 2015). It is usually used in the form of smoking or in food. As crude drug derived from the plant cannabis sativa $L$, it is one of the most widely abused illicit drugs not only in Nigeria but throughout the world. The National Institute of Drug Abuse (NIDA, 2015) reveals that "most users smoke marijuana in hand-rolled cigarettes called joints, among other names; some use pipes or water pipes called bongs". Historically, Cannabis Sativa which marijuana is derived from has had a long history of use (over 5000 years) starting in Central and Northeast Asia with current use spreading worldwide as a recreational drug or as a medicine (Russo, 2002).

The Drug Abuse Warning Network (DAWN), an organization responsible for monitoring the health impact of drugs, estimated that, "in 2002, marijuana was a contributing factor in over 119,000, Emergency Department (ED) visits to developing countries" which Nigeria is among, "with about 15 percent of the patients between the ages of 12 and 17 and almost two-thirds male". Still in 2002, the National Institute of Justice's Arrestee Drug Abuse Monitoring (ADAM) Programme, which collected data on the number of adult arrestees tested positive for various drugs, found that "on average, 41 percent of male youth's arrestees and 27 percent of adult female are seen to have tested positive for marijuana" (Adam, 2012).

Fried and Smith,( 2001) observed that when marijuana is smoked, "its effects begin immediately after the drug enters the brain and last from 1 to 3 hours; If marijuana is consumed in food or drink, the short-term effects begin more slowly, usually in 30 minutes to 1 hour, and last longer, for as long as 4 hours". Maldonado and Defonseca, (2002) added that "smoking marijuana deposits several times more delta -9-tetrahydro-cannabinol (THC) into the blood than does eating or drinking the drug". For them, "within a few minutes after inhaling marijuana smoke, an individual's heart begins beating more rapidly, the bronchial passages relax and become enlarged, and blood vessels in the eyes expand, making the eyes look red. The heart rate, normally 70 to 80 beats per minute, may increase by 20 to 50 beats per minute or, in some cases, even double".

Johnston and Bachman (2009) found that "as THC enters the brain, it causes a user to feel euphoric or "high" - by acting in the brain's that respond to stimuli such as food and drink as well as most drugs of abuse". They stated that "THC activates the reward system in the same way that nearly all drugs of abuse do, by stimulating brain cells to release the chemical dopamine". According to Anthony (2012), "a marijuana user may experience pleasant sensations, colours and sounds may seem more intense, and time appears to pass very slowly. The user's mouth feels dry, and he or she may suddenly become very hungry and thirsty. His or her hands may tremble and grow cold. The euphoria passes after awhile, and then the user may feel sleepy or depressed". Pope and Yurgelun-Todd (2006) noted that "heavy marijuana use impairs a person's ability to form memories, recall events and shift attention from one thing to another". The National Highway Traffic Safety Administration (NH TSA, 2000) stated that "THC also disrupts coordination and balance, by 
binding the receptors in the cerebellum and basal ganglia; parts of the brain that regulate balance, posture, coordination of movement and reaction time. Through its effects on the brain and body, marijuana intoxication can cause accidents". Johnston and Bachman (2009) studies show that "approximately 6 to 11 percent of fatal accident victims test positive for THC".

\subsection{The Social outcomes of Marijuana on Human Behaviour}

Marijuana use has also attracted considerable scholarly attention from the Social Science world. As revealed by Adeyemi (2008:4), marijuana use "is a social problem that has spread and increased rapidly in recent decades across diverse segments of countries of the world, constituting a threat to the effective functioning and survival of the society". The use of marijuana frequently as observed by him, especially among vulnerable young people "has caused a significant burden on individuals and societies throughout the world" (Adeyemi, 2008). The World Health Report (2002) equally indicated that "8.9 percent of the total burdened disease is associated with the use of psychoactive substances".

More so, Ajayi and Ekundayo (2010) stated that "youths who smoke marijuana are more likely than non-users to have problems on their jobs, such as increased absences, tiredness, accidents, poor interpersonal relationship at work, poor attitude to work and negative social interaction at work". Equally, marijuana use and anti-social behaviour among youths has also been found by Ajayi and Ekundayo (2010). According to them, "most of the marijuana users in most communities often engage in organized crimes such as secret cults (gangs), drug trafficking, prostitution and youth homicides and other related social and criminal justice problems". They found that "young offenders are versatile in committing other types of antisocial behaviour including heavy drinking, dangerous driving and promiscuous sex".

Writing on the attitudes of youths who engage in drug abuse, Fabuyi (2000), asserted that the general survey on drug abuse situation in Nigeria carried out in 1999 through the Rapid Situation Assessment (RSA) showed that "60 percent of youths (mainly between 10-29 years old) are found to be using drugs including marijuana, and that unruly behaviours have been found among them". Thus, the social effects of marijuana on human behaviour are obvious. The commonly observed social effects in many of the Nigerian communities including ours are: Family break downs, violence and destruction, child abuse, sexual abuse, disrespect and break down of law and order in families and society; lost of individual dignity, respect and self worth; financial mismanagement and loss of property and destruction of family hope (NDLEA, Akwa Ibom State Command, 2015b).

Inciardi, Horowitz and Pottieger (2003: 35-37) argued that "marijuana use and crime relationship is interactive". Crime, they pointed out, "finances the use of drugs; continuous usage of drugs encourages more use of drugs and more use of drugs encourages more crime". They stated that "it is unquestionable that a large proportion of youths who get involved with criminal justice agencies (the police, the courts and custodian institutions) are usually regular drug users like cocaine, marijuana and tobacco".

The United Nation Report (2009), showed that "the use of illegal drugs is inclusive and crimes go hand in hand". In so many cases, "drug users such as marijuana and tobacco will literally do anything to obtain enough money to satisfy their drug use habits". Parker (2006) opined that "the most frequently committed unwanted behaviours by marijuana users are criminal in nature". According to Parker (2006), "marijuana users tend to gain most income by theft, prostitution and drug peddling. He strongly declared that "there are some apparent relationships between marijuana use and criminal behaviour; a number of these are: crimes committed under the influence of drugs; crimes committed in order to get money or goods to buy drugs and trafficking and a host of other crimes associated with drug distribution". Bennett (2008) in examining the connection between drug use and criminal behaviour stated that "marijuana use causes crime as well as other drugs". According to him "these crimes or offences are motivated by the need for money or goods to buy drugs. Examples of such crimes could include theft of different kinds, snatching, robbery and kidnapping".

Similarly, Goldstein (2005) argued that "drug users such as marijuana, cocaine and alcohol are more frequently involved in crimes like assault, family quarrels, and disrespect to elderly ones, violent crimes and prostitutions. Goldstein further explained that "there is a causal relationship between marijuana use and violent behaviour". Equally, in establishing the social effect of marijuana use on human behaviour, Sommers and Baskins (2009), interviewed 156 women from two New York City neigbours with high concentration of drug use. They found that "respondents were engaged in a wide range of criminal activities, and almost all of them caught admitted to being experienced drug users; 70 percents of them were regular crack users, 38 percent reported involvement in robbery, 44 percent were at times involved in prostitution, others were reported to be involved in assaults". The researcher concludes that "drug use sustains violence crimes and other related criminal behaviours within a large social setting".

On the other hand, Bennett (2008) research among sample of 225 arrestees, found that "75 percent of the subjects were tested positive for at least one drug, marijuana". He observed that "the criminal offences that correlated with the use 
of drugs were income generating offences such as multiple type of theft, many shopliftings and handling stolen goods, corruption, fraud, embezzlement, money laundering, promiscuous sex and child abuse". According to Abdullahi, Deribe and Mustapha (2014), "the social implications of drug use such as marijuana on youth's behaviour can best be understood when seen from the abusers relationship with his immediate community in the following areas: Moral decay, school dropout, high rate of crime, family disintegration, prostitution and increase in number of psychopaths".

On issue of moral decay, Abdullahi et al (2014) observed that "most children today find it difficult to think or work without energy enhancing drug". He added that "most parents in the family front find it difficult to control their children who are under the influence of drug and as a result of this; most children no longer have respect for their parents". According to them, "this moral decay affects not only families but also traditional and other constituted authorities". For them, "youths under the influence of drug molest their parents and commit all sort of social and economic crimes; some even take their parents to police stations and courts and hold authority to ransom and the country at large". They found that "youths no longer respect their motherland or its constitutions; they kill under the influence of hard drugs, rape and steal from their blood relations without feelings of guilt".

\subsection{Psychological Outcomes of Marijuana on Human Behaviour}

How tetrahydro-cannabinol (THC) acts in the brain to produce its many effects has been documented. According to Maldonado and Defonseca, (2002), "when someone smokes marijuana, THC rapidly passes from the lungs into the bloodstream, which carries the chemical to organs throughout the body, including the brain". In the brain, "the THC connects to specific sites called cannabinoid receptors on nerve cells and thereby influences the activity of those cells. Some brain areas have many cannabinoid receptors; others have few or none". Breivogel and Beletskaya, 2003) showed that "many cannabinoid receptors are found in the parts of the brain that influence pleasure, memory, thought, concentration, sensory and time perception, and coordinated movement". The diagram in Table 1 shows marijuana effects on the brain.

Table 1: Marijuana's Effects on the Brain

\begin{tabular}{|l|l|}
\hline Brain Region & Functions Associated with Region \\
\hline Brain regions in which cannabinoid receptors are abundant \\
\hline Cerebellum & Body movement coordination \\
\hline Hippocampus & Learning and memory \\
\hline $\begin{array}{l}\text { Cerebral corlex, especially cingulated, frontal, and } \\
\text { parietal regions }\end{array}$ & Higher cognitive functions \\
\hline Nucleus accumbens & Reward \\
\hline $\begin{array}{l}\text { Basal ganglio } \\
\text { Substantia nigra pars reticulate } \\
\text { Entopeduncular nucleus } \\
\text { Globus pallidus } \\
\text { Putamen }\end{array}$ & \\
\hline Brain regions in which cannabinoid receptors are moderately concentrated \\
\hline Hypothalamus & Movement control \\
\hline Amygdola & $\begin{array}{l}\text { Body housekeeping functions (body temperature regulation, salt and water } \\
\text { balance, reproductive function) }\end{array}$ \\
\hline Spinal cord & Emotional response, fear \\
\hline Brain stem & Peripheral sensation, including pain \\
\hline Central gray & Sleep and arousal, temperature regulation, motor control \\
\hline Nucleus of the solitary tract & Analgesia \\
\hline
\end{tabular}

Source: NIDA Research Report Series, 2005

As could be deduced from Table 1, marijuana is a psycho-active drug. The word 'psycho active' literally means "working (active) on the mind or behaviour and other processes" (Allan, 2003). Psychoactive or psychopharmacologic drugs are identified to act on the central nervous system, to indicate the interaction between the drug and the psychological characteristics of the organism (Allan, 2003). Akinola (2008) observed that "the above drugs are highly potent on the mind of the abuser and are liable to influencing his mood and behaviour and these are drugs that can change or affect the way a person thinks, feels, or acts". 
These are drugs, which by law are prohibited for use except for medical purposes. This is so because they usually have psychological effect on the mind and the senses. Marijuana is one of the major psychoactive drugs mostly abused in various communities in Nigeria. Adesina, (2005) observed that " the use of psychoactive substances such as marijuana among adolescents and young adults has become a subject of public concern worldwide partly because of its potential to contribute to unintentional injuries". He stated that "the brain can solve problems, be creative, be logical, make plans, make wide decisions and do almost anything else one can think of ; all parts of the brain work together, to keep one healthy, intelligent and happy". NDLEA, (2015a) therefore concludes that "when one takes marijuana, parts of the brain start to disagree on what to do and that creates a big problem".

Youths use drugs for many reasons, a part from curiosity; it makes them good, reduce stress, and to make them feel grown up. Akafor and Sanusi (2004) stated that the psychological effects of marijuana on human behaviour are: sleeplessness, difficulty in keeping track of time, impairment of short-term memory which reduces one's ability to perform tasks requiring concentration and coordination. In addition, marijuana blocks the messages going to brain and alters perception. In the words of Abubakar (2009), it increases the rate of the mentally deranged persons in the society due to brain damages. Idowu (2002) also stated that mental illness is a contributing factor to marijuana use resulting from brain malfunctioned.

National Drug Law Enforcement Agency (NDLEA, 2015a) stated that "the psychological effects of marijuana on human behaviour are: affect abusers alertness, and damages brain cells controlling thinking, emotion, pleasure, coordination, mood and memory which affects individuals judgmental abilities skill's and aspects of problem solving" (Drug Demand Reduction Unit. NDLEA, Akwa Ibom State Command, 2015b). Pope, Gruber, Huestis and Yargelun Todd (2001) added that "marijuana intoxication can cause distorted perceptions, impaired coordination, difficulty in thinking and problem solving and problems with learning and memory". Also, research conducted by Tashkin (2000) shows "association between chronic marijuana use and increased rates of anxiety, depression, suicidal thoughts and schizophrenia among youths".

Pope, et al, (2001) research has shown that "Marijuana has adverse impact on memory and learning". For example, a study of 129 college students who were heavy users of marijuana disclosed that "those who smoked the drug at least 27 of the preceding 30 days, critical skills related to attention, memory, and learning were significantly impaired, even after they had not used the drug for at least 24 hours". The heavy marijuana users in the study "has more trouble sustaining and shifting their attention and in registering, organizing and using information than did the study participants who had used marijuana not more than 3 of the previous 30 days". As a result, "someone who smokes marijuana once daily may be functioning at a reduced intellectual level all of the time" says (Pope, et al, 2001). More recently, Pope, et al, (2001) showed that "a group of long-term heavy marijuana users' ability to recall words from a list was impaired 1 week following cessation of marijuana use, but returned to normal by 4 weeks". The implication of this finding is that "even after long-term heavy marijuana use, if an individual quits marijuana use, some cognitive abilities may be recovered" Pope, et al, (2001).

\subsection{The Economic outcomes of Marijuana on Human Behaviour}

Marijuana use has some economic effects on the behaviour of youths. Chinkere and Mayowa (2011) emphasized that "addiction to drug such as marijuana leads to economic wastage". Obianwu (2005) confirmed that "cannabis is by far the most commonly used illicit drug with usage of 4 percent of the world population compared to 1 percent for all other drugs combined which has rendered youths between ages 10-25 poor and irresponsible". Akinyemi (2008) reported that "despite the efforts of Nigerian National Drug Law Enforcement Agency (NDLEA) and other governmental agencies to stem the tide of marijuana use in Nigeria, there has been a consistent rapid rise in the number of cases of marijuana users among young people (ages 10-24) in Nigeria". The implication on the individual user is high monetary expenditures used in buying the drug and for medical and other treatment services for these in times of sickness (Gropper, 2005).

Furthermore, Sanni, Udoh and Ezeh (2010), identified "vandalism, weapon carrying, rape, examination malpractices, school violence, building, cultism, truancy and anti-social behaviours often associated with drug abuse such as marijuana and alcoholism". They found out that "when youths are caught by the Law Enforcement Agencies like the police, money which they suppose to use and cater for their welfare is usually paid to Police for their bail-out". In agreement with this fact, the Drug Demand Reduction Unit; NDLEA, Akwa Ibom (2015b) reported that "economic effect of marijuana on youth's behaviour is financial mismanagement and loss of property". According to them, "youths who are deeply involved in taking marijuana and are addicted to it finds it difficult to make financial plans and could not manage the money they have". They kept spending the totality of their income on marijuana each time they feel like taking it and by so doing reduce their financial capacity. According to Obianwu (2005) the use of illegal drugs like marijuana has 
precipitated a lot of drug related automobile accidents and health problems including interference with normal reproductive functions and long term damage to the brain, heart and lungs. According to him, these are serious health problems that requires large amount of expenditure for treatment which hard drug users must face.

\subsection{Theoretical Framework}

Social Learning theory has relevance to the understanding of marijuana use and its outcomes on youth's behaviour. This theory explains the role of reinforcement in learning and continuation of behaviour (Skinner, 1969). The central idea that underlies the theory is the belief that " people learned through a process of social reinforcement". It implies therefore that "people who use marijuana are playing the role of reinforcing the behaviour of their friends. Corroborating this assertion is findings from the work of Bandura (1976) which indicate that "people who used drugs such as marijuana are those individuals that are in search of solutions to a problem". From social learning perspective, marijuana use is perceived as a problem solver and a type of reinforcement. That is, "those who continued to use drugs are the people who have realized that drugs are fulfilling the function for which they are taken". In essence, users do not consider the effect on physical, social, psychological life, otherwise they would have hid to the warning "smokers are liable to die young" as encrypted on packages of cigarettes.

\section{Research Methodology}

\subsection{Research Design}

The survey design was adopted for the study. Data were obtained from the respondents through the use of questionnaire. The area of study was Ibesikpo Asutan Local Government Area of Akwa Ibom State.

\subsection{Population and Sample of the Study}

The population of the study consisted of 137,101 (male 72,795 and female 64,306) people in the 79 villages of the two clans making up the LGA (National Population Census, NPC; 2006). Since the study area is large and it was impossible to study the entire population; the study used simple random sampling technique to select 20 villages from the 79 villages making up the area. The use of snow ball sampling technique was used to select 200 marijuana users (10 respondents each from the 20 villages).Therefore a total of 200 respondents constituted sample size of this study.

\subsection{Method of data collection and analysis}

The research instrument was a 35-item structured questionnaire. Two hundred (200) questionnaire were administered to 200 sampled respondents but only 197 questionnaire were returned and found useful for data analysis. Simple percentages were used in the analysis of respondents' bio-data and answering the research questions while chi-square statistics $\left(\mathrm{x}^{2}\right)$ was used to test the null hypotheses.

\subsection{Data Analysis}

Table 2: Distribution of subjects into sub variable groups by frequency counts

\begin{tabular}{|lccc|}
\hline SIn Variables & Sample & Frequencies Percentage \\
1. Sex & Male & 140 & 71.1 \\
& Female & 57 & 28.9 \\
\hline \multirow{2}{*}{ 2. Age } & $12-13$ & 24 & 12.2 \\
& $197-15$ & 66 & 33.5 \\
\hline \multirow{2}{*}{ 3. Educational attainment } & $16-17$ & 107 & 54.3 \\
\cline { 2 - 5 } & Non-formal & 10 & 5.1 \\
4. Occupation & 197 Primary & 29 & 14.7 \\
& Secondary & 158 & 80.2 \\
\hline
\end{tabular}




\begin{tabular}{|c|c|c|c|}
\hline 5. Marital status & 197 Single & 197 & 100 \\
\hline \multirow{3}{*}{ 6. Religion } & Christianity & 197 & 100 \\
\hline & 197 Traditional religion & 0 & 0 \\
\hline & Muslim & 0 & 0 \\
\hline \multirow{2}{*}{ 7. Have you used marijuana before? } & 197 Yes & 148 & 58.3 \\
\hline & ${ }^{191}$ No & 49 & 19.3 \\
\hline \multirow{4}{*}{ 8. In what form do you take it? } & Smoking & 48 & 20 \\
\hline & 197 Mixed with hot drink & 61 & 24 \\
\hline & $\begin{array}{l}\text { MIIXed with rood } \\
\text { Chewing }\end{array}$ & 30 & 12 \\
\hline & & 9 & 4 \\
\hline 9. Does taking marijuana have any ch & $197 \begin{array}{l}\text { Yes } \\
\text { No }\end{array}$ & $\begin{array}{c}113 \\
84\end{array}$ & $\begin{array}{l}45 \\
33\end{array}$ \\
\hline
\end{tabular}

Data on Table 2 shows that 140 (71.1\%) were male respondents while $57(28.9 \%)$ were female. It revealed that more male than female formed the sample of this study. This variation suggests that more male than female adolescents use marijuana. Twenty- four (24) (12.2\%) of the respondents were between the age brackets of 12-13, $66(33.5 \%)$ of the respondents were between 14-15 age cohorts, while 107 (54.3\%) respondents were between 16-17 years. The data revealed that adolescents age between 16 and 17 likely use marijuana in the study area. Ten (5.1\%) out of 197 respondents had attended non-formal education, 29 (14.7\%) attended primary school, and 158 (80.2\%) were in secondary schools. Also, item 4 shows that 187 (94.9\%) were students and 10 (5.1\%) were non-employed. In addition, item 5 shows that all (197) of the respondents (100\%) were single; and all of the $197(100 \%)$ were Christians; none was of Muslim or traditional religious faith. Item 7 shows that 148 (58.3\%) respondents agreed to have used marijuana; whereas, 49 (19.3\%) disagreed. Of the 148 respondents who agreed to have smoked marijuana, 61 (24\%) mixed with hot drink, $30(12 \%)$ agreed to have mixed marijuana with food while $9(4 \%)$ by chewing. Items 9 shows that $113(45 \%)$ of the respondents agreed that taking marijuana produces some changes in their behaviour; whereas, $84(33 \%)$ respondents disagreed.

\subsection{Testing of Hypotheses}

Ho1: Marijuana use has no significant effect on the behaviour of adolescent youths in Ibesikpo Asutan Local Government Area.

Table 3: Chi-square analysis of the responses on the effect of marijuana use on the behaviour of adolescent youths in Ibesikpo Asutan Local Government Area

\begin{tabular}{|c|c|c|c|c|c|c|}
\hline Marijuana use and behavioural outcomes & Yes & No & Total & $\mathrm{x}^{2} \mathrm{cal}$ & $\mathrm{x}^{2}$ crit & DF \\
\hline $\begin{array}{l}\text { Does taking marijuana ever made you } \\
\text { being violent? }\end{array}$ & 185(112.8) & 12(84.2) & 197 & & & \\
\hline $\begin{array}{l}\text { Does taking marijuana ever made you } \\
\text { break law or order in your family } \\
\text { and community } \\
\text { Does taking marijuana ever made }\end{array}$ & $53(112.8)$ & 144(84.2) & 197 & & & \\
\hline you to be hostile? & $96(112.8)$ & 101(84.2) & 197 & 246.62 & 9.488 & 4 \\
\hline $\begin{array}{l}\text { reddening of your eyes? } \\
\text { Does marijuana intake makes you feel }\end{array}$ & 106(112.8) & $91(84.2)$ & 197 & & & \\
\hline dizzy and sleepy & 124(112.8) & 73(84.2) & 197 & & & \\
\hline
\end{tabular}

In Table 3, since the calculated chi-square value of 246.62 exceeded the critical value of 9.488 at the degree of freedom of 4 and at 0.05 significant level, the null hypothesis which state that "marijuana use has no significant effect on the behaviour of adolescent youths in Ibesikpo Asutan Local Government Area" was rejected; whereas, the alternate hypothesis which state that "there is a significant effect of marijuana use on the behaviour of the youths in Ibesikpo Asutan" was accepted. This implies that "some behaviours of adolescent youths in Ibesikpo Asutan are significantly associated with the use of marijuana". 
Ho2: There is no significant association between marijuana use and disrespectful behaviour among adolescent youths in Ibesikpo Asutan Local Government.

Table 4: Chi-square analysis of the responses on the association between marijuana use and disrespectful behaviour among youths in Ibesikpo Asutan Local Government

\begin{tabular}{|c|c|c|c|c|c|c|}
\hline Marijuana and disrespectful behaviour & Yes & No & Total & $\mathrm{x}^{2} \mathrm{cal}$ & $x^{2}$ crit & DF \\
\hline $\begin{array}{l}\text { Do you normally talk abusively to } \\
\text { people after taking marijuana? } \\
\text { Does taking marijuana make you to } \\
\text { disrespect your parents and elders? } \\
\text { Do you get upset unnecessarily after } \\
\text { taking marijuana? } \\
\text { Does taking marijuana ever made you } \\
\text { to disrespect constituted authorities in } \\
\text { your community? } \\
\text { Are you always delighted to offend } \\
\text { and insult people after taking } \\
\text { marijuana? }\end{array}$ & $\begin{array}{c}73(118.8) \\
101(118.8)\end{array}$ & $13(78.2)$ & 197 & 196.28 & 9.488 & 4 \\
\hline
\end{tabular}

The result of test of $\mathrm{HO}_{2}$ in Table 4 showed that calculated $x^{2}$ cal value of 196.28 exceeded the $x^{2}$ crit of 9.488 at degree $4 \mathrm{~d} / \mathrm{f}$ and 0.05 significant level, therefore the null hypothesis was rejected; while, the alternate hypothesis was accepted. The result indicates that "the disrespectful behaviour of adolescent youths in Ibesikpo Asutan was associated with marijuana use".

Ho3: There is no significant association between marijuana use and criminal behaviour among adolescent youths in Ibesikpo Asutan Local Government.

Table 5: Chi-square analysis of the responses on the association between marijuana use and criminal behaviour among youths in Ibesikpo Asutan Local Government.

\begin{tabular}{|c|c|c|c|c|c|c|}
\hline Marijuana use and criminal behaviour & Yes & No & Total & $\mathrm{x}^{2} \mathrm{cal}$ & $\mathrm{x}^{2}$ crit & DF \\
\hline $\begin{array}{l}\text { Does marijuana use encourage theft in } \\
\text { the society? } \\
\text { Does taking marijuana ever }\end{array}$ & 138(114.4) & $59(82.6)$ & 197 & & & \\
\hline $\begin{array}{l}\text { encourage high rate of cultism? } \\
\text { Have you ever been arrested }\end{array}$ & 123(114.4) & $74(82.6)$ & 197 & & & \\
\hline because of marijuana use? & 58(114.4) & 139(82.6) & 197 & 129.56 & 9.488 & 4 \\
\hline $\begin{array}{l}\text { government property atter taking } \\
\text { marijuana? } \\
\text { Does taking marijuana encourage }\end{array}$ & 159(114.4) & $38(82.6)$ & 197 & & & \\
\hline killing of innocent souls in your community? & $94(114.4)$ & $103(82.6)$ & 197 & & & \\
\hline
\end{tabular}

In Table 5, the calculated chi-square value of 129.56 exceeded the critical value of 9.488 at the degree of freedom of 4 and 0.05 level of significance. The null hypothesis which states that there is no significant association of marijuana use and criminal behaviours among youths in Ibesikpo Asutan was rejected. The study therefore accepted the alternative hypothesis. The implication of the above finding was that "criminal behaviours among youths in Ibesikpo Asutan were significantly associated with the use of marijuana".

Ho4: Financial mismanagement is not a statistically significant effect of marijuana use among adolescent youths in Ibesikpo Asutan Local Government. 
Table 6: Chi-square analysis of the responses on marijuana use and financial mismanagement among youths in lbesikpo Asutan Local Government

\begin{tabular}{|c|c|c|c|c|c|c|}
\hline Marijuana use and financial mismanagement & Yes & No & Total & $\mathrm{x}^{2} \mathrm{cal}$ & $\mathrm{x}^{2}$ crit & DF \\
\hline $\begin{array}{l}\text { Does marijuana use encourage } \\
\text { unnecessary spending? }\end{array}$ & $132(107.8)$ & $65(91.4)$ & 197 & & & \\
\hline $\begin{array}{l}\text { Do you normally spend money to } \\
\text { buy marijuana? }\end{array}$ & $108(107.8)$ & $89(91.4)$ & 197 & & & \\
\hline $\begin{array}{l}\text { Have you ever spent money on } \\
\text { medical treatment as a result of the } \\
\text { use of marijuana? } \\
\text { Do you find it difficult sometimes } \\
\text { to make financial plans because }\end{array}$ & $72(107.8)$ & $125(91.4)$ & ) 197 & 196.17 & 9.488 & 4 \\
\hline & $173(107.8)$ & $24(91.4)$ & 197 & & & \\
\hline and your family financial up-keep? & $54(107.8)$ & $154(91.4)$ & 197 & & & \\
\hline
\end{tabular}

In Table 6, given that the calculated chi-square value 196.17 exceeded the critical value of 9.488 at the degree of freedom of 4 and at 0.05 level of significance, the null hypothesis which states that "Financial mismanagement is not a statistically significant effect of marijuana use among adolescent youths in Ibesikpo Asutan Local Government." was rejected; whereas, the alternative hypothesis was accepted. This implies that financial mismanagement among youths in Ibesikpo Asutan was one of the effects of marijuana use.

\section{Discussion of Findings}

\subsection{Marijuana use and its effects on the Behaviour of adolescent Youths}

Finding on marijuana use and behavioural effects among adolescent youths in Ibesikpo Asutan Local Government Area, Akwa Ibom State revealed a significant positive association between the variables. The respondents agreed that using marijuana predisposed them to be violent. Sometimes being hostile, having dizzy feelings and sleepiness were also identified by the respondents as the influence with which marijuana use have on them. These findings are in line with the findings of Abiodun and Ogunyemi (2010) who found that "drug abuse such as marijuana encourages violence and breakdown of laws and order among undergraduate students of the University of Lagos, Nigeria". This finding is also consistent with the findings made by the NDLEA; Akwa Ibom State Command (2015), that drug abuse such as marijuana causes family breakdowns, disrespect and breakdown of laws and order in the families and society.

\subsection{Marijuana use and Disrespectful Behaviour}

The result of this study equally revealed a significant association between marijuana use and disrespectful behaviour among adolescent youths in the study area. The respondents agreed to talk abusively to people after taking marijuana. They also agreed that marijuana use influences them to disrespect their parents and elders, get upset unnecessarily, offend and insult people and also disrespect constituted authorities in their communities. This findings is in line with the findings of Abdullahi, Deribe and Mustapha (2014), who earlier noted that most children no longer have respect for their parents, tradition and constituted authorities when they are under the influence of drug; and that most parents find it difficult to control such children.

\subsection{Marijuana use and Criminal Behaviour}

Result of the association between marijuana use and criminal behaviour among adolescent youths in the study area equally proved significantly positive. Respondents acknowledged the fact that marijuana use encourages criminal behaviour in the society. Such unruly behaviour as pick pocketing, shoplifting, theft and vandalism were said to be common among marijuana smokers. This finding supports earlier finding by Abdulahi (2011), who found that youths under the influence of marijuana usually kill, rape and steal from their blood relations and feel normal. 


\subsection{Marijuana use and Financial Mismanagement}

Finding of the study also showed a statistically significant association between marijuana use and financial mismanagement among the study group. Respondent identified irresponsible spending as a challenge faced by them in the cause of smoking marijuana. This finding confirmed that of Sanni, Udoh and Ezeh (2010), who found that youths who are deeply involved in taking marijuana finds it difficult to make financial plans; and they keep spending the totality of their income on marijuana each time they feel like taking it, and by so doing reduces their financial capacity. Money spend on health issues caused by marijuana smoke is not an exception.

\section{Conclusion/ Recommendations}

Based on the findings of this study, it is concluded that marijuana use has significant behavioural outcomes on adolescent youths in Akwa Ibom State. The study discovered disrespectful behaviour, memory impairment, criminal behaviours as well as financial mismanagement as those possible outcomes associated with marijuana use. In view of these, the following recommendations of the study were made:

(i) Parents and guardians should be watchful over their wards and educate them about the dangers of using marijuana. They should have knowledge of the friends and company their wards keep; since smoking is a learned behaviour. In the same vein, Social Welfare and Community Development Ministries should devise means of encouraging parents to report delinquents children who are drug users to the ministry so that professionals will be sent to guide and counsel such parents and children.

(ii) To fight against marijuana use and other hard drugs, law enforcement agencies in Nigeria should not focus on the drug dealers (cultivators, smugglers, pushers, transporters and financiers) alone but also on the smokers which are scattered everywhere in the streets, drinking spots and motor parks.

(iii) Campaigns against marijuana use should be incorporated in health education curriculum for primary, secondary, and tertiary institutions with special focus on the adverse consequences of drugs.

(iv) The establishment of counselling units for drug prevention and control in community health facilities and schools as well as the recruitment of qualified health counsellor is needful in helping drug addicts by giving them special advice on how to go about the withdrawing from its use.

(v) The Mass media should intensify efforts on the campaign against the use of hard drugs. More awareness need be created particularly in the rural areas. Existing NGOs and CBOs should equally support the media in this direction.

(vi) The National Agency for Food, Drugs Administration and Control (NAFDAC), as well as the National Drug Law Enforcement Agency (NDLEA) should collaborate in the war against illicit drugs. They should shun bribe and corruption and drugs offenders should be apprehended and prosecuted accordingly and appropriate sanctions meted out to them to serve as deterrent to others.

\section{References}

Adams, I. \& Martin, B. (2006). Cannobis: pharmacology and toxicology in animals and humans edition: 1585-1614

Abdu-Raheem. B. (2013). Sociological factors to drug abuse and the effects on secondary school students academic performance in Ekiti and Ondo States, Nigeria. Contemporary issues in Education Research 6 (2): 233-239.

Abdullahi. M., Deribe. A \& Mustapha. K. (2014). An evaluation of the impacts of drug use and abuse among youth in Borno State, Nigeria. International Journal of Humanities and Social Science Invention 3(12): $50-55$.

Abdulkadir, Y. (2011). Court jails seven for smoking Indian hemp. Daily Trust News paper of Tuesday April 12.

Abubakar, S. (2009). Nigerian teens involved in drugs-NDLEA. Daily Trust News paper of Thursday June 1.

Adesina, S. (2005). The use of Indian hemp and drugs among secondary school students in Lagos. Lagos: University press.

Agbonghale, G \& Okaka, R. (2014). Effects of drug abuse on academic performance of technology education students in Nigeria public Universities. Journal of Psychology 5(1): 79-83.

Ajayi, I. \& Ekundayo, H. (2010). Contemporary issues in educational management. Lagos: Derate Nigeria Ltd.

Akanbi, M. \& Ajiboye, A. (2014). Impact of substance abuse on academic performance among adolescent students of colleges of education in Kwara State, Nigeria. Scholarly journal of Education. 3 (7): 75-79.

Akinola. F. (2008). Nigeria among top drug-producing countries. Sunday Trust NewsPaper. March $9^{\text {th }}$.

Akinyemi, K. (2008). Pushing the drug war in the south west. Daily Trust, 30 November 008.

Allan, C. (2003). Drugs alcohol and mental health. Cambridge: Cambridge University press.

Alabi, T. (2012). Unemployment and poverty; the twin fertilizer for youth criminality. Global Journal of Social Sciences, 2(2): 29-32

Anthony, J. (2012). Drug dependence epidemiology. Clinical Neuroscience Research. 5:55-68. 
Bandura, A. (1976). Self- reinforcement; theoretical and methodological consideration. Behaviourism. 4:55-59.

Bennett, T. (2008). Drugs and Crime: The results of the second development of the New-ADAM Programs: Home Office Study 205. London: Home Office.

Breivogel, C. \& Beletskaya, I. (2003). The effects of delta-9 tetrahydrocannabinol physical dependence on brain cannobinoid receptors Euro J Pharmacology 459:139-150.

Chikere, E. \& Mayowa, M. (2011). Prevalence and perceived health effect of alcohol use among male undergraduate students in Owerri, South-East Nigeria: a descriptive cross sectional study. BMC Public Health. 11, 118.

Fabuyi, A. (2000). Effects of drug abuse on adolescent youths. Lagos: University press.

Fayomo, G. (2000). Drug education and its effects on the educational performance of some adolescents drug abusers in Ibadan" The Counsellor, drug abusers in Ibadan" The Counsellor, 18(5)

Fried, P. \& Smith, A. (2001). A literature review of the consequences of prenatal marijuana exposure: An emerging theme of a deficiency in aspects of executive function. Neurotoxicology and Teratology 239(1): 1-11.

Goldstein, P. (2005). The drug/violence nexus: A tripartite conceptual framework. Journal of Drug Issues 14493-687 Florida: Florida University School of Criminology and Criminal Justice System.

Gropper, R. (2005). Consequences of youth substance abuse. www.ojjdp.gov.../drugid/ration.

Idowu, A. (2002). The problems of drug abuse in Nigeria: Implications for the family. A paper presented at the $16^{\text {th }}$ Annual Conference of the Counselling Association of Nigeria, held at Bayero University Kano, $27^{\text {th }}$ and $28^{\text {th }}$ August.

Inciardi, J. A., Horowitz, R. \& Pottieger, A. E. (2003). Street Kids, Street drugs, Street Crimes. Belmont, CA: Wads Worth.

Maldonado, R. \& de Defonseca, F. (2002). Cannabinoid addiction: Behavioual models and neural correlates. Journal of Neuroscience 22 (9): 3326-3331.

National Drug Law Enforcement Agency, NDLEA (2015a). Information on drug trafficking. NDLEA Drug Data Collection. Lagos: Drug Demand Reduction Unit.

NDLEA (2015b). Akwa Ibom State Command (Drug Demand Reduction Unit), 291, Nwaniba Road. Uyo: Akwa Ibom State.

National Drug Law Enforcement Agency, NDLEA, (2006).Drug date collection and research, Lagos: Drug Demand and Reduction Unit.

National Drug Intelligence Center (2011). The economic impact of Illicit drug use on American society. Washington D.C: United States Department of Justice.

National Institute on Drug Abuse (NIDA, 2015). Research Report sense.www.drugabuse.gov.

National Highway Traffic Safety Administration (NHTSA) (2000). Marijuana and alcohol combined severely impede driving performance. Annals Emer Med 35(4): 398-399.

Obianwu, H. (2005). Emerging serious psychopathology associated with abuse of cannabis (Indian hemp, marijuana). Tropical Journal of pharmaceutical research, 4, (10, 329-330.

Omage, E. \& Oshiloya R. (2006). Perception of drug abuse amongst Nigerian. Undergraduate World Journal of Medical Science. 2(1) 29.

Omboto, J. (2013). Factors influencing youth crime and juvenile delinquency. International Journal of Research in Social Sciences 1(2): 31-35.

Osarenren, N. (2002). Child Development and Personality. Lagos: Derate Nigeria Ltd.

Parker, G. (2006). Taking on substance abuse in the emergency from: One hospital spirit story. Int Journal of mental Health Addiction 2,(1):1-7.

Pope, H. \& Yurgelun-Todd, D. (2006). The residual cognitive effects of heavy marijuana use in college students JAMA 275(7): 527.

Pope, H. Gruber, A., Huestis, M. \& Yurgelun-Todd, D. (2001). Neuropsychological performance in long-term cannabis users. Arch Gen Psychiatry 58 (10): 909-915.

Russo, E. (2002). Cannabis treatments in obstetrics and gynecology: A historical review. Journal of Cannabis Therapeutics 2(3-4), 5-35.

Sanni, B., Udoh, N. \& Ezeh, L. (2010). Family type and juvenile delinquency, issues among secondary school students in Akwa Ibom State, Nigeria: Counselling implications. Journal of Social Science, 23(1): 21-28.

Skinner, B.F. (1969)contingencies of reinforcement. New York: Apple-Century-crofts.

Sommers, I. \& Baskin, D. (2009). Situational or Generalized Voiolence in Drug Dealing. Journal of Drug Issue . 27(4) Florida: Florida University School of Criminology and Criminal Justice System.

Staff, K. (2012). "Drug use on the rise among Nigerian. Youths. http://news2onlinenigeria.com/news/top-stories/144286-drug-use-on-therise-amongNigeria-

Tashkin, D. (2000). Pulmonary complications of smoked substance abuse. West J. Med 152:525-530.

UNODC, (2005). World Health Organization. Expert Committee on Dependence Producing Drugs. Fourteenth Report Urban Adolescent. Child Development. 61:2032-2046.

United Nations Report (2009). The United Nations Drug Control. New York: United Nations. 